\title{
КРУГЛЫЙ СТОЛ «ВЛИЯНИЕ ИСТОРИЧЕСКИХ ФАЛЬСИФИКАЦИЙ И МИФОВ НА СОЗНАНИЕ И СОЦИАЛЬНОЕ ПОВЕДЕНИЕ СОВРЕМЕННОЙ РОССИЙСКОЙ МОЛОДЕЖИ»
}

\author{
С. В. Алексеев \\ (Московский гуманитарный университет)
}

\begin{abstract}
Аннотация: В статье информируется о проведении в Московском гуманитарном университете 13 мая 2015 2. круглого стола «Влияние исторических фальсификаций и мифов на сознание и социальное поведение современной российской молодежи».
\end{abstract}

Ключевые слова: Московский гуманитарный университет, круглый стол, история, исторические фальсификации, российская молодежь.

\section{THE INFLUENCE OF HISTORICAL MYTHS AND FALSIFICATIONS ON THE CONSCIENCE AND SOCIAL BEHAVIOR OF THE CONTEMPORARY RUSSIAN YOUTH: A ROUNDTABLE}

\author{
S. V. Alekseev \\ (Moscow University for the Humanities)
}

\begin{abstract}
This is a brief overview of the roundtable devoted to the influence of historical myths and falsifications on the conscience and social behavior of the contemporary Russian youth. The roundtable took place on 13 May 2015 in Moscow University for the Humanities.

Keywords: Moscow University for the Humanities, roundtable, history, historical falsifications, Russian youth.

13 мая 2015 г. в Московском гуманитарном университете состоялся круглый стол «Влияние исторических фальсификаций и мифов на сознание и социальное поведение современной российской молодежи». Мероприятие проводилось в рамках одноименного социально значимого исследовательского проекта. При реализации проекта используются средства государственной поддержки, выделенные в качестве гранта в соответствии с распоряжением Президента Российской Федерации от 17.01.2014 № 11-рп и на основании конкурса, проведенного Фондом ИСЭПИ. Проект реализуется Московским гуманитарным университетом.
\end{abstract}


Со вступительным словом к участникам обратился директор Института фундаментальных и прикладных исследований МосГУ доктор философских наук, профессор В. А. Луков. Руководитель проекта д. и. н., проф. С. В. Алексеев ознакомил участников мероприятия с основными результатами проводимого исследования. Д. и. н. О. А. Плотникова охарактеризовала методологические подходы к понятиям «миф» и «фальсификация», сформулированные в ходе работы. Д. и. н., проф. Б. А. Ручкиным были представлены результаты опроса экспертов по молодежной проблематике, посвященного воздействию на молодежь исторической мифологии. Специалисты Центра социологии молодежи ИФПИ МосГУ д. э. н. В. А. Гневашева и к. с. н. С. В. Луков представили итоги исследования исторической осведомленности молодежи, проведенного в 2014-2015 г.

В докладах и выступлениях в дискуссии подчеркивалось, что отсутствие в российском обществе согласия по важнейшим проблемам отечественной истории деструктивно отражается на историческом сознании молодежи, что при общем низком уровне исторической осведомленности, под воздействием исторических фальсификаций и мифов в молодежной среде происходит подмена реальной исторической памяти как элемента гражданского сознания негативной мифологией, а это ведет к развитию социального нигилизма и экстремистских тенденций.

В работе круглого стола приняли участие специалисты из Московского гуманитарного университета, Московского государственного университета им. М. В. Ломоносова, Московского педагогического государственного университета, Российского университета дружбы народов, Института российской истории РАН, Национального института бизнеса, других научных и образовательных центров Москвы и регионов России, преподаватели школ, представители СМИ и издательского бизнеса. Как отмечается в рекомендациях круглого стола, необходимо укреплять взаимосвязи между учреждениями системы образования, общественными организациями, государством и молодежью по вопросам формирования исторического сознания молодежи в процессе ее социализации и патриотического воспитания. Предложены конкретные меры по поддержке и развитию историко-просветительской деятельности, научнопопулярного книгоиздания.

Алексеев Сергей Викторович - доктор исторических наук, професcop, заведующий кафедрой истории Московского гуманитарного университета, председатель Историко-просветительского общества «Радетель». Адрес: 111395, Россия, г. Москва, ул. Юности, д. 5, корп. 3. Тел.: +7 (499) 374-55-81. Эл. адрес: ipo1972@mail.ru 
Alekseev Sergey Viktorovich, Doctor of History, Professor and Chair, Department of history, Moscow University for the Humanities; Chair, "Radetel" Historical and Educational Society. Postal address: Bldg. 3, 5 Yunosti St., Moscow, Russiat Federation, 111395. Tel.:+7 (499) 374-55-81. E-mail: ipo1972@mail.ru 